role of the pituitary gland and the kidney; Mr. B. J. Frost, of the University of Canterbury, New Zealand, to a Rutherford Scholarship for three years to continue working in the Department of Psychology, Dalhousie University, Halifax, Canada, on an investigation of the interaction of excitatory and inhibitory processes in colour vision.

\section{The Paul Instrument Fund Awards}

The Paul Instrument Fund Committee has made grants as follows: $£ 1,000$, as a supplementary grant, to Prof. W. R. S. Garton, professor of physics, and Dr. R. C. M. Learner, research associate at the Imperial College of Science and Technology, for completion of the construction of a high-resolution, broad-range spectrograph; $£ 3,200$ to R. L. Gregory, university lecturer in experimental psychology and Fellow of Corpus Christi College, Cambridge, for the development and building of an instrument designed to minimize atmospheric and other disturbances in astronomical telescopes; $£ 2,500$ to Dr. W. J. Jones, of the University Chemical Laboratory and Fellow of Trinity College, Cambridge, for the construction of laser apparatus for the excitation of Raman spectra; $£ 1,850$ as a supplementary grant, to Sir John McMichael, professor of medicine in the University of London and director of the Department of Medicine, Postgraduate Medical School of London, for the continuation of the development of a miniature electromagnetic flowmeter.

The Paul Instrument Fund Committee, composed of representatives of the Royal Society, the Institute of Physics and the Physical Society and the Institution of Electrical Engineers, was set up in 1945 "to receive applications from British subjects who are research workers in Great Britain for grants for the design, construction and maintenance of novel, unusual or much improved types of physical instruments and apparatus for investigations in pure or applied physical science".

\section{University News:}

Keele

THe following appointments have been made: R. T. Beattie (lecturer in the Department of Psychology); Dr. D. B. Cook (post-doctoral Fellow in the Department of Theoretical Physics and Theoretical Chemistry); T. F. Webber (Research Fellow in the Department of Biology).

London

Dr. A. N. DAvison has been appointed to the chair of biochemistry tenable at Charing Cross Hospital Medical School. The following readers have also been appointed: Dr. A. P. Mathias (biochemistry, tenable at University College); Dr. J. L. Knill (engineoring geology, tenable at the Imperial College of Science and Technology). The following titles have been conferred: Professor, Dr. M. Freedman (anthropology, in respect of his post at the London School of Economics and Political Science); Dr. A. L. Greenbaum (biochemistry, in respect of his post at University College). Reader, Dr. J. D. Billimoria (chemical pathology, in respect of his post at Westminster Medical School); Dr. A. J. Smith (geology, in respect of his post at University College); Dr. W. M. Watkins (biochemistry, in respect of her post at the Lister Institute of Preventive Medicine).

Manchester

The following lecturers have been appointed: B. Cox and Dr. T. R. Wilson (pharmacology).

\section{Newcastle upon Tyne}

THE following lecturers have been appointed: Mr. D. Brook (statistics in the Department of Mathematics); Dr. R. H. Pain and Mr. R. Virden (biochemistry); Mr. B. J. Miflin (plant science).
Sheffield

The following lecturers have been appointed: Dr. G. Coleman (biochemistry); Dr. T. F. Mortimer (pathology); Dr. W. T. Raynes (chemistry). The title of reader in botany has been conferred on Dr. J. Webster.

Southampton

THE following appointments have been made: Reader. ships, Dr. A. W. Bright (electrical engineering); Dr. L. G. E. Bell (zoology); Senior Lectureships, W. A. Matthews (psychology); Lectureships, K. J. Binns (electrical engineering); Dr. J. A. Betts and D. R. Wilkins (electronics); Dr. F. A. Bostock, Dr. M. S. P. Eastham, I. J. Ketley, L. G. Proll, Dr. B. S. Westcott, N. L. Biggs, G. M. Phillips and P. J. Taylor (mathematics); Dr. R. D. Wills (physies); Dr. W. T. Drabble, Dr. B. J. Parsons and Dr. G. N. Woodruff (physiology and biochemistry); Dr. F. S. Billett (zoology).

\section{Announcements}

THE Alvarenga Prize for 1965 has been awarded by the College of Physicians of Philadelphia to Dr. Harry F. Harlow, director of the Primate Research Center, University of Wisconsin, Madison, for his work on social deprivation in monkeys.

Ar the annual general meeting of the Royal Statistical Society on June 16, Mr. L. H. C. Tippett was elected president for the year 1965-66. Mr. B. P. Emmett, Miss S. V. Cunliffe and Dr. J. A. Heady were re-elected honorary secretaries and Mr. W. Rudoe was elected honorary treasurer. Prof. C. R. Rao was awarded the Guy Medal in Silver of the Society.

A REgIONAI meeting of the Association of Applied Biologists will be held in Newcastle during September 14-17. Further information can be obtained from $\mathbf{F}$. Blackburn, Department of Plant Science, the University, Newcastle upon Tyne 1.

THE 452nd meeting of the Biochemical Society will be held jointly with the Italian Biochemical Society in Santa Margherita during September 7-8. Further information can be obtained from the Biochemical Society, 20 Park Crescent, London, W.I.

An international colloquium on "The Optical Properties and Electronic Structure of Metals and Alloys" will be held in Paris during September 13-16. Further informa. tion can be obtained from Prof. F. Abelès, Institut d'Optique, 3 Boulevard Pasteur, Paris 15.

A GENERAL discussion of the Faraday Society on "Intermolecular Forces" will be held at the University of Bristol during September 14-16. Further information can be obtained from the Assistant Secretary, the Faraday Society, 6 Gray's Inn Square, London, W.C.I.

A MeEting of the British Radio Spectroscopy Group on "Magnetic Resonance in Metals" will be held in the University of Leeds during September 13-14. Further information can be obtained from Dr. E. F. W. Seymour, Department of Physics, the University, Leeds 2.

AN international conference on "The Microwave Behaviour of Ferrimagnetics and Plasmas" will be held at the Institution of Electrical Engineers during Septem. ber 13-17. Further information can be obtained from the Secretary, Institution of Electrical Engineers, Savoy Place, London, W.C.2.

A CONFERENCE on "Machines for Environmental and Materials Testing", organized by the Institution of Mechanical Engineers and the Society of Environmental Engineers, will bo held at the Manchester College of Science and Technology during September 6-10. Further information can be obtained from the Conference Section, Institution of Mechanical Engineers, I Birdcage Walk, London, S.W.1. 